\title{
Prostate cancer metastases to the rectum: A case report
}

\author{
Tariq O Abbas, Abdulla R Al-Naimi*, Rafie A Yakoob, Issam A Al-Bozom and Abdulkader M Alobaidly
}

\begin{abstract}
Prostate cancer rarely metastasis to the rectum. Findings in the patient reported here emphasize the importance of the relationship between urinary and gastrointestinal symptoms in detecting prostatic neoplasms in older male patients.
\end{abstract}

\section{Background}

Prostate cancer has the potential to advance locoregionally to adjacent organs. This spread can take place via different routes, including direct invasion and through lymphatic channels. It is very rare for prostate cancer to metastasize to nearby organs, including the rectum. We describe here a patient presenting with prostate cancer metastasizing to the rectum.

\section{Case report}

A 60-year-old man was referred to our urology facility after experiencing severe weight loss $(30 \mathrm{~kg}$ in 3 months) and bleeding from the rectum, together with upper abdominal pain and vomiting. Over the previous year, he had experienced painless hematuria and voiding difficulty.

He was thoroughly examined, including undergoing a colonoscopy, which revealed a distal rectal sessile mass lying about $15 \mathrm{~cm}$ from the anal verge [Figure 1]. Histopathologic examination of the biopsy showed that it was a metastatic prostatic adenocarcinoma [Figure 2].

A CT scan of his abdomen showed that the prostatic mass had invaded the urinary bladder wall and that the biopsied mass was separate from the rectum [Figure 3]. His serum PSA concentration was high $(983 \mathrm{ng} / \mathrm{ml})$. In addition, TC-99 MDP bone scintigraphy showed widespread bone metastatic lesions [Figure 4].

He was started on hormone therapy and followed up by the oncology department.

\section{Discussion}

Prostate cancer is a slowly growing neoplasm that can easily be missed during its early stages. Patients not previously diagnosed with prostatic adenocarcinoma may present initially with metastases [1]. In contrast, PSA may not be expressed in all patients with prostatic adenocarcinoma [2].

Prostate cancer extension to colorectal tissue can occur through at least 3 potential routes. The first is direct invasion through Denonvilliers fascia and infiltration into the rectum. The second is through lymphatics, since the prostate and rectum share some lymphatic drainage to groups of pelvic lymph node [3]. Third, prostate cancer cells can spread through needle biopsy, by seeding into peri-rectal or rectal tissue along the needle biopsy; this, route, however, is extremely rare $[4,5]$.

Prostate cancer metastasis to the recto-sigmoid region can occur by subserosal metastatic implant of the malignant tissues [6]. The incidence of rectal infiltration by prostatic adenocarcinoma is extremely rare, being encountered on average once every two years by a busy colorectal practice [7].

\section{Conclusion}

Findings in the patient reported here emphasize the importance of the relationship between urinary and gastrointestinal symptoms in detecting prostatic neoplasms in older male patients. Careful immunohistochemical examination of specimens can prevent major surgical interventions in favor of hormonal and radiological therapies.

\footnotetext{
* Correspondence: naimiar@hotmail.com
}

Hamad General Hospital, Doha, Qatar 

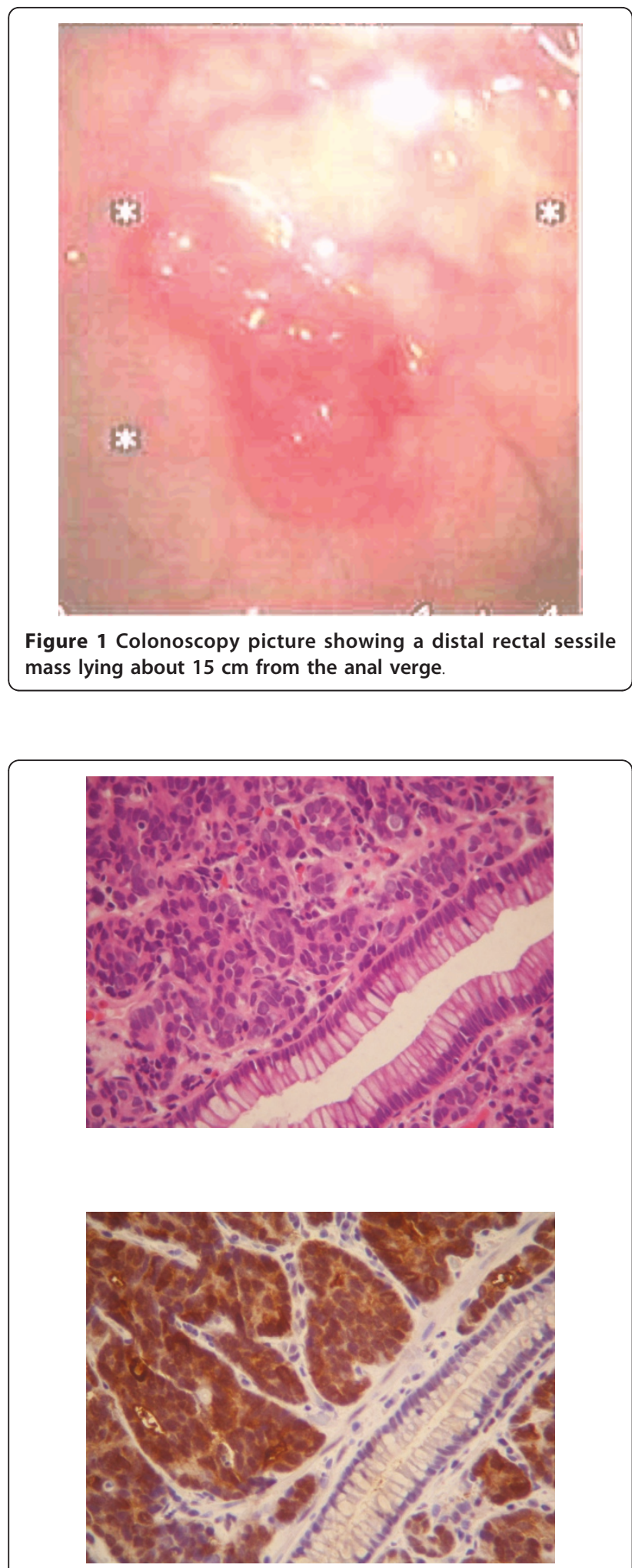

Figure 2 (Top) Sections showing tumor acini adjacent to a normal colonic crypt (Hematoxylin \& Eosin $\times 400$ ); (Bottom) Staining of the same microscopic focus with anti-PSA antibody, showing that tumor cells were positive while normal colonic crypts were negative (immunohistochemistry-PSA $\times 400$ ).

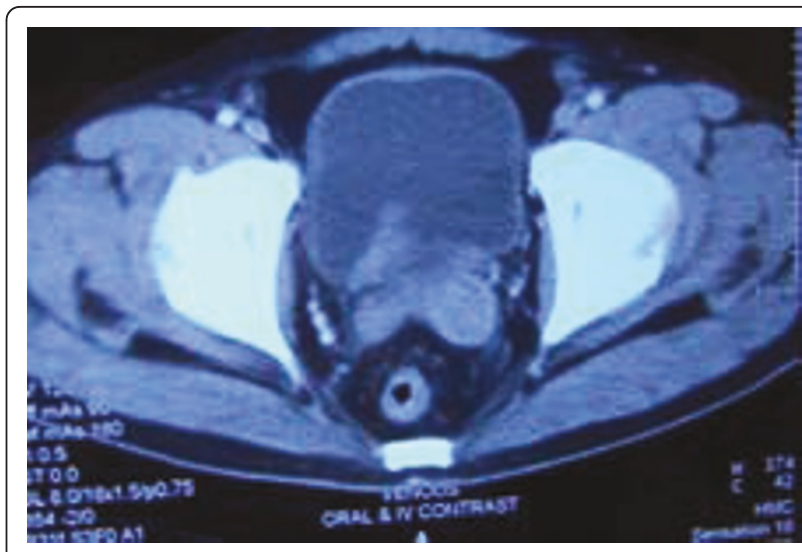

Figure $3 \mathrm{CT}$ scan of the abdomen showing the prostatic mass invading the urinary bladder wall and being separate from the rectum

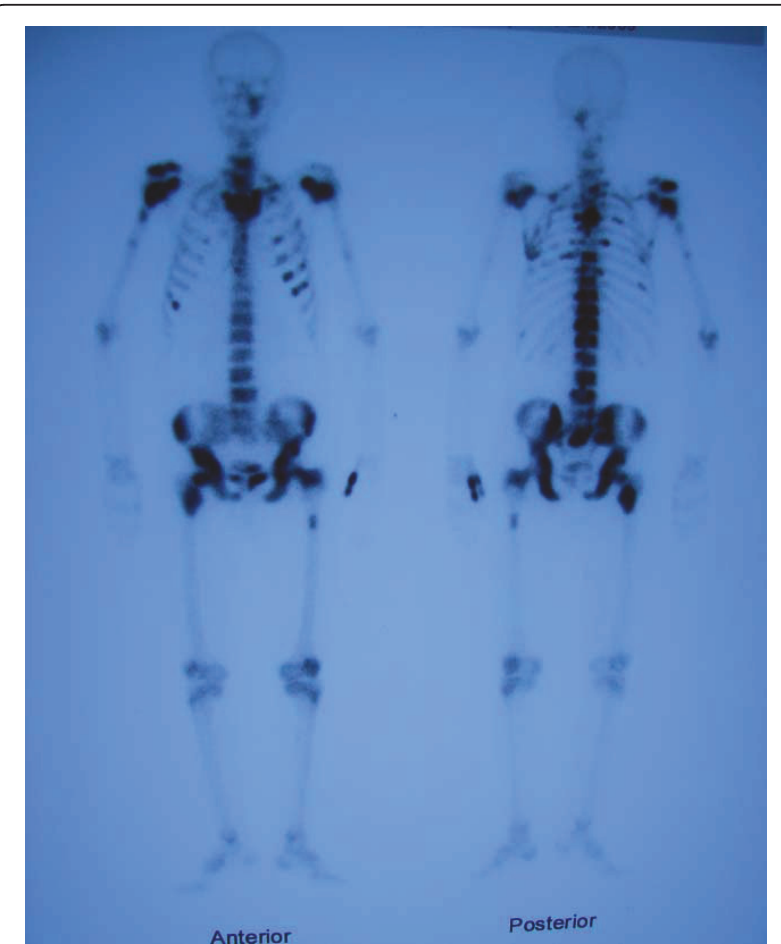

Figure 4 TC-99 MDP bone scintigraphy showing widespread bone metastatic lesions.

\section{Consent}

Written informed consent was obtained from the patient for publication of this case report and accompanying images. A copy of the written consent is available for review by the Editor-in-Chief of this journal.

\section{Authors' contributions}

TA carried out the history, physical examination and the provisional draft AAN participitate in the sequence alignment and drafted the manuscript again. IAB carried out the histopathology. 
RY carried out the colonoscopy and the re ctal biopsy.

AA involoved in the patient management and data collection.

All authors read and approved the final manuscript.

\section{Competing interests}

The authors declare that they have no competing interests.

Received: 19 June 2010 Accepted: 21 May 2011 Published: 21 May 2011

\section{References}

1. Hematpour K, Bennett CJ, Rogers D, Head CS: Supraclavicular lymph node: incidence of unsuspected metastatic prostate cancer. Eur Arch Otorhinolaryngol 2006, 263(9):872-874.

2. Gallee MP, Visser-de Jong E, van der Korput JA, van der Kwast $T H$, ten Kate FJ, Schroeder FH, Trapman J: Variation of prostate-specific antigen expression in different tumour growth patterns present in prostatectomy specimens. Urol Res 1990, 18(3):181-187.

3. Murray SK, Breau RH, Guha AK, Gupta R: Spread of prostate carcinoma to the perirectal lymph node basin: analysis of 112 rectal resections over a 10-year span for primary rectal adenocarcinoma. Am J Surg Pathol 2004, 28(9):1154-1162.

4. Vaghefi H, Magi-Galluzzi C, Klein EA: Local recurrence of prostate cancer in rectal submucosa after transrectal needle biopsy and radical prostatectomy. Urology 2005, 66:881.

5. Lane Z, Epstein Jl, Ayub S, Netto GJ: Prostatic adenocarcinoma in colorectal biopsy: clinical and pathologic features. Hum Pathol 2008, 39(4):543-549.

6. Gengler L, Baer J, Finby N: Rectal and sigmoid involvement secondary to carcinoma of the prostate. Am J Roentgenol Radium Ther Nucl Med 1975, 125(4):910-917.

7. Bowrey DJ, Otter MI, Billings PJ: Rectal infiltration by prostatic adenocarcinoma: report on six patients and review of the literature. Ann $R$ Coll Surg Engl 2003, 85:382-385.

doi:10.1186/1477-7819-9-56

Cite this article as: Abbas et al:: Prostate cancer metastases to the rectum: A case report. World Journal of Surgical Oncology 2011 9:56.

\section{Submit your next manuscript to BioMed Central and take full advantage of:}

- Convenient online submission

- Thorough peer review

- No space constraints or color figure charges

- Immediate publication on acceptance

- Inclusion in PubMed, CAS, Scopus and Google Scholar

- Research which is freely available for redistribution

Submit your manuscript at www.biomedcentral.com/submit 